AperTO - Archivio Istituzionale Open Access dell'Università di Torino

\title{
Spatialities of Control (Turin 2006)
}

\section{This is the author's manuscript}

Original Citation:

\section{Availability:}

This version is available http://hdl.handle.net/2318/1512446

since 2016-07-07T15:31:23Z

Publisher:

Palgrave Macmillan

Terms of use:

Open Access

Anyone can freely access the full text of works made available as "Open Access". Works made available under a Creative Commons license can be used according to the terms and conditions of said license. Use of all other works requires consent of the right holder (author or publisher) if not exempted from copyright protection by the applicable law. 


\title{
SPATIALITIES OF CONTROL (TURIN 2006)
}

\author{
Alberto Vanolo \\ Dipartimento Culture, Politica e Società \\ Università degli Studi di Torino (Italy) \\ alberto.vanolo@unito.it
}

DRAFT

Final version published as: "Spatialities of Control (Turin 2006)", in V. Bajc (ed.), Surveilling and Securing the Olympics. From Toyko 1964 to London 2012 and Beyond, Palgrave MacMillan, New York (2016), pp. 297-318.

\begin{abstract}
The chapter offers an analysis of the organization, the performance and the perceptions involved in the surveillance and security management activities carried on during the 2006 Torino Winter Olympic Games. The research, conducted mainly through analysis of policy and security documents, newspaper articles and by interviews with local scholars, workers and spectators, will focus on the organization of spaces, on the practices of surveillance, and on the technologies involved in the management of the bodies of the spectators and the staff in order to guarantee security in the performance of the public ritual of the Games. First, the event is be framed in the specific geographical and social context of Torino and the Piedmont region. Next, security threats are discussed with reference to the local context, particularly by analysing technical and planning documents and newspapers discussing the various presumed menaces to security. Then, the governance system and the organization of security spaces are presented. Finally, the last part of the paper discusses the different views and perceptions of politicians, spectators and urban social movement opposing the Games.
\end{abstract}




\section{Introduction}

Turin, a city in north-western Italy with a population of about 900,000 and a metropolitan area of about 1.5 million was the host of the 2006 Winter Olympics. As the capital of the Piedmont region of 4.3 million inhabitants, Turin is the fourth largest Italian city. The headquarters of the automobile manufacturer Fiat made the city known as the Italian capital of automobile production and as such has often been compared to Detroit. ${ }^{1}$ As in many other cities dominated by one corporation, the general crisis of the Fordist style factory manufacturing starting in the late 1970s has been dramatic, thus laying the foundation for a debate on the economic future of the city. Following a devastating automobile crisis in 1996, the metropolitan administration lunched an initiative to support the city's economic diversification and a change of its industrial image.

The bid for the Games was officially won in 1999 in Seoul. The Torino Organizing Committee of the XXth Olympic Winter Games of 10-26 February 2006 was officially created that same year and became known as TOROC (Torino Organizing Committee). Agenzia Torino 2006 and other organizations were later added to the complex governance mechanism which constituted the management of the Games. There was substantial political and popular support for this new policy which aimed to change Turin from an industrial city to an economically diversified international city. The successful bid for the Games needs to be understood in this context. This attitude was well expressed by the mayor:

"As the biggest sporting event, the Games constitute an opportunity for urban regeneration, visibility, and international positioning. Already started and well on the way, the Olympics are an attempt to build new Turin which will connect its economic tradition with renewal of its infrastructure and cultural and tourist attractions."

The Olympic Games provided an opportunity to show to the world Turin's "new" urban profile. In this sense, in the eyes of the politicians and urban promoters, it was imperative to avoid any kind of problems, including threats to security, in order to sustain a narrative of urban success, perfection, and good impeccable organization. This narrative was broadcast on television screens all over the world. As a person responsible for the Police forces explained:

"The attention of the whole world was not only on Turin and other municipalities involved in the Games but also on the presence of grassroots movements opposing the Games. This situation imposed on us adoption of a security system encompassing the venues as well as the urban and provincial spaces where the Games took place. This security system ensured a planned execution of the Games and safety for everyone who participated, be it directly or indirectly. The relevance of the XXth Winter Olympic Games and IXth Winter Paralympic Games is such that, to guarantee the international image of Italy, the Games must proceed within a framework of maximum security. ${ }^{2}$

In popular and political discourses, the Olympics have for the most part been celebrated as a great success for the city, particularly in terms of its international promotion. Yet, the Games represented a major challenge for the redevelopment of both the physical layout of the metropolitan area as much as the Olympic valleys. The Olympic "theatre" was much wider than the city boundaries and included seven municipalities in the mountain valleys of the Province of Torino. This Olympic geography also included five logistic warehouses, two car parks, media villages, and an anti-doping laboratory.

As is well known, Winter Olympics are significantly smaller than the Summer Games. As we can see in Table 1 , Torino hosted 2633 athletes and 84 medal events. This pales by comparison to the previous host city, Athens, where 10,600 athletes competed in 301 medal events during the 2004 Summer Games. Nevertheless, Turin's 900,000 inhabitants were swamped by the 1.1 million tourists who visited the city in 2006. The shortage of hotel rooms was such that the city officials asked the residents to help accommodate this huge influx of tourists by renting their homes or certain rooms of their home to the visitors. 


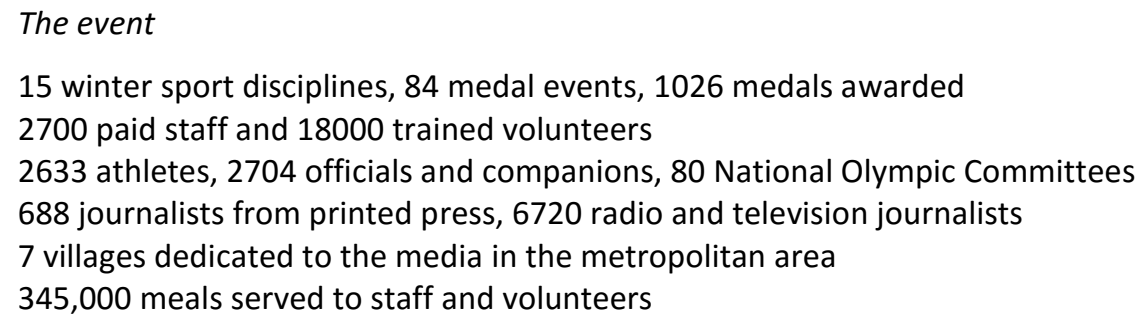

The spectators

About 900,000 tickets sold (out of 1,128,000 available tickets)

$59 \%$ of the purchased tickets were for urban sporting events, $36 \%$ for mountain events, $5 \%$ for ceremonies 172,000 tickets (19\%) sold to corporate partners

$70 \%$ of sales to the general public were to persons from Italy, followed by Switzerland (6\%), Germany (6\%), France (6\%), Norway (3\%), USA (3\%).

About 1.1 million tourists in 2006

The material structures

5100 computers

90,000 accreditation badges

8000 square meters of PVC applied to the outside of the buildings with Games logos

The safety system

1740 TOROC personnel (paid and volunteers) with tasks connected to safety and surveillance

202 x-ray machines

463 metal detectors

922 hand wands (hand-held metal detectors)

Source: All data from Torino 2006, Final Report (official concluding report developed for the IOC)

Below I analyze the complex governance and management system, designed to coordinate between the Organizing Committee and the surveillance and security forces. I focus on how technologies were implemented through the organization of space, describe surveillance practices, and discuss the experiences and perceptions of surveillance by the people involved in the Games. For this analysis, I consulted a number of different documents: Olympic management documents, the Olympic bid, the Host City Contract, the final report on the Games, debriefing materials, documents from the Italian police forces, strategic planning documents from security and safety managers, mass media reports, and secondary data. Between June and September 2009, I also conducted formal interviews and informal conversations with various people who were involved in the Games.

\section{Defining threats to security}

Prevention of threats to security entails what Michel Foucault referred to as biopolitical practices. Such practices control actions of individuals, for example, denying them access to specific places and in this way, limiting their mobility in space. The definition of what is allowed and what is not allowed, that is, the boundary between "reasonable" and "excessive" control over the practices of the local population and the actors in the Olympic event is a delicate issue which is often politically and socially contested.

The question of detection and classification of potential threats to security became an interesting issue. An initial list of potential perils was compiled by a technical team lead by the Torino Organizing Committee safety manager and presented in a Preliminary Strategic Plan elaborated by Torino Organizing Committee 
in 2002. ${ }^{3}$ Threats compiled in this list were divided into two general categories. The first category included risks connected to traffic conditions, bad weather, fires, floods, and other environmental disasters; accidental and malicious technological risks, and risks connected to image of the national prestige and the Olympic family. The second category of risks was referred to as "severe risks" and included terrorism in the form of violent demonstrations and public protests, disorders by non-global movements, and organized crime. The Minister of the Interior responsible for security matters was quoted as saying that "security planning for the Olympics means continuously updating elements connected to scenario dynamics," implying that the list had to be considered as merely indicative rather than complete. ${ }^{4}$ Indeed, there was a striking difference between the abovementioned list of "severe risks," which was published in a confidential document meant to be used only internally and all successive Torino Organizing Committee documents which were made public. In fact, this list of security threats disappeared from the later documents all together, creating a possibility - at least publically if not internally - for more amicable attitudes towards demonstrations and social movements. An official responsible for the Police Forces later explained to me that "respect of constitutional freedoms and respect for the right of those intending to manifest and express their ideas in a peaceful way had to be guaranteed" but did not comment about the disappearance of the initial list of security threats. ${ }^{5}$

The local imaginary of fear was articulated in mass media coverage and in planning documents in the form of two "severe risks." At the forefront of terrorist fears was Islamic fundamentalism. Examples of this "threat" were newspaper articles titled "Torinistan and the Olympic truce" or "Assault risk for Olympics and elections" which warned the public that "among recurrent menaces of Islamic-inspired attacks, attempts to revise a new armed party alarmed no global itches (...) but this is not a reason to be joyful" ${ }^{6}$ As also expressed by the Minister of the Interior, "because of their worldwide echo, the Turin Olympics run the risk to raise a great interest in the eyes of Al Qaeda's strategists". ${ }^{7}$

Equally threatening to security of the Olympics was a long lasting conflict surrounding a high-speed railway project in Val di Susa, a valley north-west of Turin which was a part of the Olympic landscape. The local population and environmentalist organizations, only partially interested in sports events, were fiercely opposed to the railway project. Their activism was seen as a threat and was represented by the mass media as responsible for terrorist attacks. Apprehension against these activists grew even stronger after protesters succeeded in altering the path of the Olympic torch, prompting the local media to turn against them with titles such as "The torch surrenders to anti-[rail]." ${ }^{8} \mathrm{As}$ an official connected to the police explained in an interview:

The national political situation, the international scenario, the situation emerging in Valle di Susa as a consequence of the [high-speed railway] works required, at least for the duration of the Olympic and Paralympic Games, the planning of a system which would guarantee order and public security, it required setting up a complex system of vigilance over potential targets in Turin and the province. ${ }^{9}$

Some protest movements denounced severe repression by the police during that period and the impossibility of practicing what Lefebvre (1968) calls people's "right to the city". Part of it was related to the evacuation of squatter houses in the city centre shortly before the Games. One of these squatter houses had been occupied since 1986 and was evacuated in July 2005. Today, the building houses a travel office for students. ${ }^{10}$ By September, only four months before the Games, two other squatter houses were evacuated. The official reasons behind these evacuations were not connected directly to the Games but to some violent incidents which occurred during a protest a few months earlier. The timing of these evacuations, however, raised suspicions, and the independent media firmly denounced what it called a repressive policy aimed at "hindering" dissident voices.

This is a particularly sensitive topic, because of the risk that security measures could be used in order to limit the possibility of public participation. The major local protest movements, named Nolimpiadi, ${ }^{11}$ denounced, particularly through the Internet and unofficial posters, a number of issues fully in line with the police framing presented above: for example, the lobbying of the urban elite in order to manage the games, environmental damage, waste of money, corruption. In particular, in 2003, the movement asked, without success, for a public referendum in order to decide whether to host the event. 
A public protest against companies providing surveillance technology, particularly companies which also provided technologies for warfare in Iraq took place as well. Technologies involved in the organization of the event were often provided by northern Italian enterprises (as Elsag Datamat) and implemented by Italian experts. In some cases, this has led to criticism from social movements that opposed the Games. For example, police forces acquired new radios, called Tetra (terrestrial trunked radio) produced by the Italian firm, Selex Communications. According to the protest movements, the purchase was just a business transaction in order to enrich Selex Communications. ${ }^{12}$ According to other voices ${ }^{13}$, acquiring the new radio system has provided and has left in the province a valuable technological heritage for local police forces. In other cases, technologies came from outside Italy, like metal detectors provided by the American company Garrett, a well known provider of Olympic security technologies. ${ }^{14}$

\section{Internet threats}

A threat not explicitly mentioned in the official documents, but discussed in popular news, ${ }^{15}$ referred to hackers and Internet attacks. The topic has not rarely been associated to ideas of "antagonism". According to a newspaper article:

"The antagonist area is also under the control of police, not just for potential clamorous acts, but because of informatics attacks. Last Friday, in fact, a so-called "netstrike" against both the official website of the Games and the Coke website has been organized (...)"16

It is curious, for example, to note the use of the expression cybersquatting with reference to the registration of commercial web domains with names similar to that of an official organization (in this case, www.torino2006.it), a phenomenon that was effectively faced by the Italian police before the Games. Put it differently, internet security has been imbued with a sort of spatial imaginary, with websites represented as spaces that may be "occupied", "attacked" and "squatted", and therefore to be "defended" and "protected".

\section{Public-Private Security Partnership}

The Host City Contract between Turin and the International Olympic Committee was quite explicit with reference to security, giving full responsibility to host countries:

"Responsibility for all aspects of security is a matter to be dealt with by the appropriate authorities of the Host Country. The City, the National Olympic Committee [i.e. CONI] and the Organizing Committee for the Games [i.e. TOROC] undertake that all appropriate and necessary security measures shall be taken accordingly." ${ }^{17}$

In the Italian case, by law, the national government is formally responsible for security. In the case of the Torino Winter Games, without denying in any way the full responsibility of the government, the public sector (the police service, but also military forces, fire brigades, medical services, etc.) cooperated with the private sector, represented by Torino Organizing Committee. Specifically, Torino Organizing Committee was assigned coordination tasks, particularly with reference to the management of what is referred to as "passive" security functions in the Olympic venues such as choices and locations of technologies and practices for security, from fences to ticket control. In the official documents, the distinction between "passive" and "active" security is only implicit and nowhere defined. By reading the documents, however, it becomes apparent that "passive" security functions refer to technologies, including identification cards, keys, locks, fences, lights, alarms. As I discuss below, Torino Organizing Committee staff was also involved in scrutinizing identification cards. ${ }^{18}$

According to Italian laws (n. 121/81), the Ministero degli Interni, the Italian ministry responsible for security, specifically through the National Council for Security, assigned to the Prefect of Torino (which is 
the representative of the Italian government in the Province) the planning and management of security issues for the Olympic event. In order to develop security coordination functions, Torino Organizing Committee organized a taskforce named TOROC Games Security, with the aim of planning and organizing surveillance for persons (for example, with metal detectors), vehicles (in specific Vehicle Screening Areas), goods (by a Vendor Certification Programme) and venues (by cameras, patrolling and other technologies). In July 2003 a Memorandum of Understanding was signed by the Prefect and Torino Organizing Committee, further clarifying the functions assigned to Torino Organizing Committee.

The strategic planning of security, coordinated by the Prefect of Torino, started about five years before the event, leading at the end of 2004 to the publication of a guideline document ${ }^{19}$ indicating specific goals to be reached in terms of security. The operative planning, coordinated by the Questura di Torino (the provincial police office), was intended as the way to reach those goals. The 2005 planning document established two more institutional bodies: one "technical taskforce", including Questore, various representatives of police forces, firemen, majors, health sector and other stakeholders; and one "operative central", a command and control centre for all police forces. ${ }^{20}$

The activities carried on by the police were managed by a central body, the Centro di Coordinamento ${ }^{21}$, and by a series of units in the various Olympic venues. Among the various functions of the central body it can be mentioned the coordination of external security forces in case of major accidents, as military forces in case of terrorism, the circulation of information between the various police and military forces, coordination with security activities of local municipalities, and particularly Protezione Civile, a voluntary service for supporting eventual emergencies. The use of police forces, by the end of the games, constituted about 9279 persons, with about 170 police officers from small municipalities in the Province, and 316 military personnel with specific surveillance tasks.

Regarding the Games security function of Torino Organizing Committee, a complex governance system was implemented during the planning period before the event. The highest level was the "head of games security", whose duty was to organize the Torino Organizing Committee planning functions, supported by an impressive number of specific managers, including the various "Venue Security Managers", the "Security Integration Manager" with coordination functions, the "Workforce Manager", responsible for workers with the help of a "Volunteers manager" and a "Paid Staff Manager", a "Transport \& Logistics Manager", regarding security in transports, a "Law Enforcement Liaison Manager" for cooperation with the police, "Security Technology Systems Management" for security instruments and technologies, "Sponsor \& NOC Liason manager" regarding enterprises and external national Olympic committees. Inside every Olympic venue, apart form the Venue Security Manager, there were a number of other managers, for example, several "Deputy Venue Security Managers" for various support activities, "Control Room Supervisor" and "Sectoral Commanders", responsible for security systems, security volunteers with patrolling and authorization-check functions, and private security guards.

During the Games, the TOROC Games Security function included a staff of 204 employees, 202 temporary external contractors, and 1536 volunteers. For the coordination of problems that could not be solved in specific venues or management areas, Torino Organizing Committee created the Main Operations Centre, a unit internal to Torino Organizing Committee whose function was to guarantee information flows during the Olympic Games to all interested organizations (for example, providing event timetables to police forces) and to manage possible critical events. Each of the potential problems emerging during the Games had to be reported to the Main Operations Centre, which classified according to severity (low, medium, high, crisis) and management scale for resolution (venue or central level, favoring when possible the lower level). A specific plan, named the "Incident and Crisis Management Plan", was ready to be implemented in case of severe crisis. The physical collocation of the Main Operations Centre was coterminous to the central body for the management of police forces (the abovementioned Centro di Coordinamento), favoring dialogue between the two bodies (see Figure 1).

The whole security system was developed on the basis of the experience of previous Olympic Games. In the framework of the process of knowledge transfer promoted by the IOC, the manager for security of Torino Organizing Committee visited and discussed the topic with managers of other Olympic cities. From my conversations with a Torino Organizing Committee safety manager, ${ }^{22}$ it became clear that the Barcelona Olympics - and the work of their main manager Santiago De Sicart - was considered a sort of "best practice" in the field. As reported in the newspapers after the Games, the head of games security of Torino 
Organizing Committee declared that the experience of Torino could now also be considered a successful example. ${ }^{23}$ According to my interview, this process of knowledge transfer from the Torino experience to the next Games started with a debriefing in Vancouver in 2006, where the purpose of the meeting was to disseminate the Italian experience by presentations, discussions, and diffusion of materials.

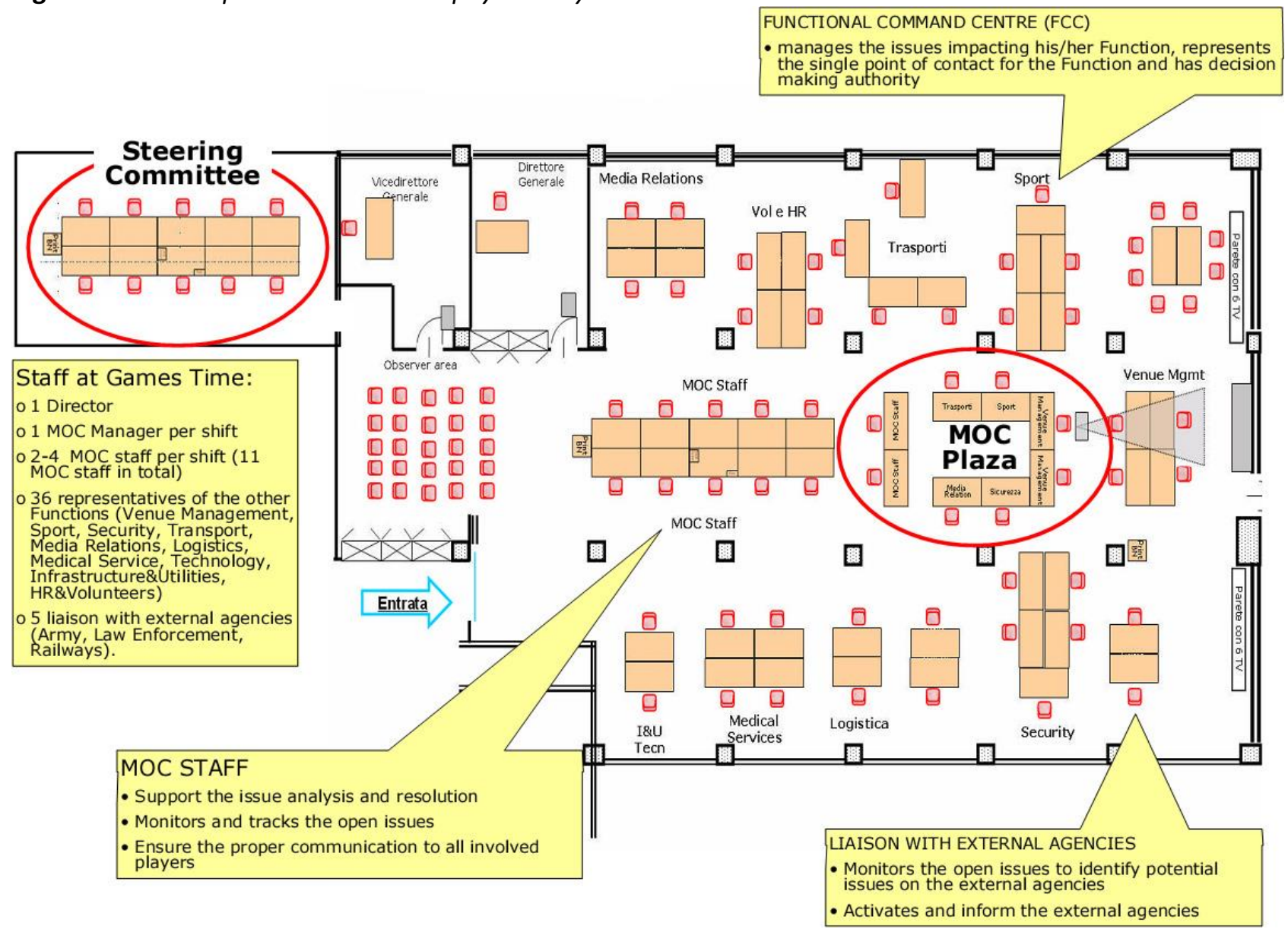

Source: File \#31, "Analysis of command, control and communication operations", in The Torino 2006 Olympic Experience. The Official Debriefing \& Final Analysis of the XX Olympic Winter Games, Torino $2006 \mathrm{dvd}$.

\section{Technologies and spaces of security}

Regarding the organization of space, Torino Organizing Committee and the police forces introduced various classifications. On a wide geographical scale, the Olympic theatre was organized in three areas with three distinct persons in charge of security: the urban space of Torino; Val di Susa and Pragelato; Pinerolo and Torre Pellice. The various venues were then classified further into three categories. Competitive venues included all tracks and courts, as ski runs or hockey fields. Non-competitive venues included the medal plaza and the media village. The residential venue referred to the Olympic villages and hotels. Each of the three categories of venues had different schedules and time-tables for security.

At the level of the single venues, the most important conceptualization of space refers to the organizing of a system of concentric rings (see Figure 2). Each venue was divided into three rings: the soft ring at the outer edge, the hard ring further towards the center, and the security ring in the heart of the venue. Looking through various documents, I found no explanation for what was meant by "hard ring". 


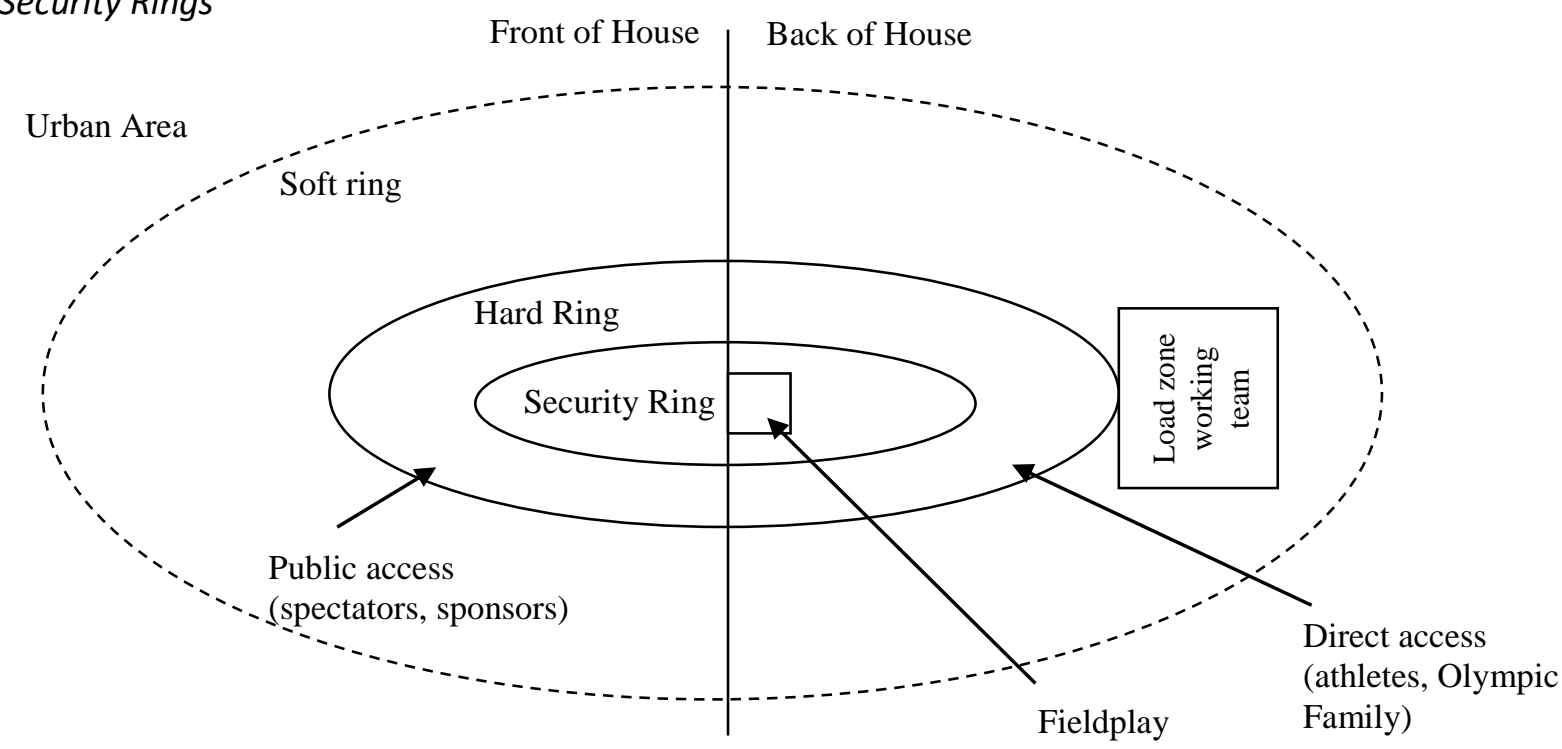

Source: personal elaboration based on interviews with security forces.

Most of the venues are characterized by just two rings: the hard and soft. The hard ring contains what was referred to as "vital structures". The concept was not clearly defined. Its boundaries are delimitated by security fences, about 2.70 meters high, security patrols, security lighting, closed-circuit television surveillance systems and anti-intrusion systems. Closed-circuit television cameras were set every 60 meters along the perimeter of the hard ring, with the addition, in some areas, of "dome" cameras characterized by high resolution (about 100 meters range). All the cameras were linked to a closed-circuit television monitor room inside the venue, and supervised by Torino Organizing Committee staff 24 hours a day.

In each of the three Olympic Villages, a third ring named security ring was planned inside the hard ring, and isolated by a 2 meters high fence: all persons entering this ring were fully inspected. I have not had the possibility to clearly define which physical structures were located inside and outside the ring, because the venue manager I interviewed had doubtful memories about that, ${ }^{24}$ and no specific mention of it can be found in planning documents. We may probably assume that the security ring hosted the rooms of the athletes.

Outside the hard ring, a soft ring includes "load" and "drop off" zones for passengers accessing the venue, parking for the vehicles with specific passes issued by the Torino Organizing Committee, and check-in for spectators. I discuss the check-in process in more detail below. The intensity of these controls depended on the nature of the venue. Competitive venues, such as the medal plaza and the Olympic stadium for the occasion of the opening ceremony had temporary security controls. The Olympic villages and media villages had permanent security controls.

Both the hard and the soft rings are each divided in the "front stage" space, or "front", and the "back stage" space or the "back of the house". Access to the back of the house was granted only to workers. This included the Olympic Family, the athletes, the media, and the Torino Organizing Committee team.

The soft ring does not have physical boundaries, but is encircled by a wider area where the planned activities include:

- wide-area controls along the perimeter of urban or mountain centers,

- random controls over suspicious vehicles or persons,

- notification of activities of groups of demonstrators wishing to get closer to the venues or important places in order to start demonstrations,

- immediate verification of alarms or signals of suspicious activity, if necessary by asking the help of police dogs or explosive experts, 
- sensitizing personnel about the need to signal to the Operative Central every anomaly or ambiguous situation that may cause troubles to the Games.

The management of these security spaces implied a large set of technologies and practices. Concerning physical enclosures, for example, different types of fences were utilized according to the material layout of spaces: strong metallic fences where possible, lighter plastic fences in areas with trees and rocks, and cement based fences near highways. To take another example, video surveillance was implemented with 700 cameras, $100 \mathrm{~km}$ of optical cables, and many hours of staff training.

As mentioned, it is also possible to refer to the defense of the virtual Internet space, since ICT experts prevented an undefined number of intrusion attempts by hackers. Concerning ICTs, it is interesting to consider, from a technical point of view, that the most sensitive information was located in a separate intranet, called Info2006 which was not accessible from the standard, global, internet, reproducing the spatial imaginary of the rigid separation between the hard and the soft ring. ${ }^{25}$

\section{Control of Behavior and Movement of Spectators}

Control over the body, the behavior, and the movement of spectators, what Michel Foucault famously referred to as biopolitics, was implemented in different ways. As emphasized in various documents, including the webpage of the Ministry of the Interior, the presence of the police had to be non-invasive and as invisible as possible, guaranteeing an enjoyable experience for the public:

"An organization of security adequate to possible menaces has been implemented. Overall, the "Olympic spirit" has prevailed, and the visibility of the police force has been kept as low as possible, always maintaining a high and vigilant level of surveillance." 26

Controls over the spectators started with the sale of the entry tickets for sporting competitions. The sale started in November 2004. Tickets were available through an internet website, a call centre with a toll free phone number, branches of a local bank, and a number of other authorized vendors. Events such as the medals ceremonies were not available for purchase to the general public. These tickets were distributed by Torino Organizing Committee free of charge only to specific guests and to some locals. On the front of each ticket, there was information in English and Italian about the venue for which the ticket was issued, the gate through which the visitor must enter with his or her specific ticket, the seating zone within which the spectator must be positioned, the seat number to which that ticket holder is assigned, the time of the event, the price, and an anti-duplication hologram (see Table 4). Visitors had to abide by "Terms and Conditions" as specified on the back of each ticket and also published on the internet and in the spectator guide which I discuss below. When seeking access to an event using such a ticket, the visitor waives a number of rights, particularly the right to disseminate for public or commercial use photos taken take by the visitor at the event, the right not to be filmed or photographed by the organizers during the event, and eventually even the right to access to the venue if the spectator opposes to specific rules of the venues.

Together with the ticket, the viewer received an "Official spectator guide", ${ }^{27}$ a 176 pages document describing "rules", "suggestions", and "information".

Concerning the rules, it was strictly forbidden for the spectator to carry objects deemed by the organizers as dangerous, including glasses, drugs, weapons, lighters, and even coins. In addition, other objects were restricted, such as large objects, cameras, smelly or noisy objects, food, and anything showing a logo or a commercial political or religious message. Once admitted, the spectator was not allowed to leave the premises. If the spectator left the premises, he or she would not be allowed to return to that same venue. The spectator guide also included "suggestions" about appropriate behavior such as not to try getting close to the venues with a private car and general information about the city and the events.

The limitation of the "commercial messages" is an interesting point. As it is well known, sponsors pay for the exclusive exploitation of the marketing of the games. For this reason, a specific part of the security activity was carried on by a team called Brand Protection Unit, which sought out and avoided the display of 
any non-sponsor logo, the so-called "ambush marketing". In order to carry out this function, for example, adhesive tape was used to hide logos, even in the case of instrumentation used for the games, as the brand of the pc monitors, and commercial activities as restaurants and bars could be fined for showing Olympic logos and brands. In the case of spectators and the working team, for example, they were not allowed access to the front rows of the venues if wearing a tee-shirt with an evident logo, and adhesive tape was used also in this case, and even on some athletes. ${ }^{28}$

The control of the body of the spectator was extended by banning the consumption of any food or drink, apart from non-commercial water, not sold by the sponsors inside the venues. As affirmed by an International Olympic Committee spokeswoman: "the IOC works hard to protect the investment of our partners. Without their contribution the Olympic Games couldn't happen the way they do". ${ }^{29}$

The most evident moment of control refers to the checking and the limiting of access to specific places, and particularly to the hard ring. The control procedures for admission to the venues were quite similar to those of an airport. First, a Torino Organizing Committee employee, called "pacer", organized the queue, gave instructions (remembering, for example, the objects not allowed), and checked the tickets, then, a policeman checked persons with a metal detector. In case of a light signal, the person was invited to empty his/her pockets into a specific box, and then to go through the portal again. A second check was then conducted by hand-wand detectors, and this was the only check, in case of peculiar situations such as wheelchair-users. At the same time, an x-ray machine checked bags. The procedure for checking bags was called "mag and bag". Objects eventually found to be prohibited had to be disposed of in a specific box. Finally, a Torino Organizing Committee employee stamped the ticket and indicated to the spectator where to go in order to enjoy the event.

\section{Surveillance of Staff and Special Guests through the Accreditation System}

Security measures were organized for the various workers connected to the event, for example, deliveries staff, athletes, journalists, Torino Organizing Committee members, cleaners, etc. The management of their bodies happened through a complex accreditation system, always associated with the exhibition of a proper identity card. I wish to draw attention to the fact that the accreditation system is so powerful as to represent a space of "exception to the norm" with reference to standard European immigration policies. Members of the IOC, national federations, national Olympic committees and specific journalists and sponsors had access to a special Olympic card that, together with a passport, allowed them to enter Italy independently from a visa. ${ }^{30}$ Members of the Olympic staff received just one card, independent of the number of their tasks. The cards were checked visually.

The accreditation system was managed by Torino Organizing Committee, and about 90,000 badges were produced. ${ }^{31}$ The system was organized in four steps: registration of potential accredited persons, confirmation, checking (by workers of the Ministero degli Interni or by police) and, finally, printing and delivery of the badges. All the accreditation requests come from organizations involved with the Games, and not from single persons. The printing and delivery of the badges happened as late as possible, in order to avoid risk of forgery. Even police forces had their accreditation badges.

Inside every venue, six different areas were accessible to people with different types of accreditation cards. For example, a specific access applied just to journalists, another one for TV cameramen, and another one for athletes. Moreover, in particularly sensitive areas, such as the playing field or the anti-doping centre, access was further restricted, allowing just those with specific additional passes. In case of loss of the pass, this was to be immediately communicated to Torino Organizing Committee accreditation centre, and badges could be withdrawn in case of violation of the norms. It was obligatory to keep the badge visible at all times when on duty.

A Torino Organizing Committee environmental manager described the inspection in the following way:

"Every morning I was submitted to mag and bag, independently of the fact that, after months of work, I knew the policeman at the entrance very well, and of my accreditation badge. It was a control similar to that in airports." 32 
Finally, specific security measures were implemented for the movement of guest stars, like celebrities or athletes receiving awards in the medal plaza. Technical details defined the distribution of police forces, the movements with cars, and the organization of radio contacts. In specific situations, snipers were located in unseen places. The management of celebrities is a complex task, partly because of the overlapping of functions between local police and foreign bodyguards and security teams.

In the case of athletes, the management of bodies was strictly connected to a complex system of transports and movements called in the documents "bubble to bubble", and referring to bus movements and security escorts to and from villages and competition venues (including airspace surveillance) and using specific supervised drop off/load in zones. From the arrival at the airport, and specifically from a guarded area, buses departed every 20 minutes for one of the three Olympic villages (in total, nine buses every hour), escorted by police officers. The movements between the villages and the venues took place along predefined routes, and inside checked buses. This system allowed the athletes to move from a "secured" place (one "bubble") to another one without having contact with the "external" world, thus making it unnecessary to check the athletes on arrival at a venue. Of course, the athletes were free to exit from the village and then come back (when they would be checked by the security agents at the entrance), but it was quite unusual for them to do so. In the case of ceremonies (like medals awards), specific escort services were organized and provided by police from the Olympic Village to the Medal Plaza and back. As shown in Figure 5, the three central cars are intended to transport the three athletes winning the gold, silver and bronze medals. It is worth to note that this is just one of the many configurations of the escort services, with variations, for example, according to the presence or absence of the anti-doping service.

A similar system was implemented for vehicles, which were considered potentially even more risky than persons, because of the many possibilities to hide forbidden objects. Every vehicle wishing to access the hard ring had to display on the windscreen a particular pass, named VAPP. In specific "vehicle screening areas", located close to the hard ring, the vehicles were checked by the police with hand wands and inspections. In case of goods deliveries, a system of "keys", including checking of the delivery schedule, the certification of inspection, and the seals of the delivered boxes was put in place. ${ }^{33}$ Moreover, in the soft ring the access to vehicles was limited to specific categories, such as residents' cars. Residents, in order to access the soft ring by car, had to display on their vehicles a specific pass showing the car's registration plate and the soft ring code.

Finally, it has to be mentioned that, throughout the city, a number of Olympic Lanes, marked by yellow stripes and Olympic symbols, were established by the Major of the city in order to allow the effective movement of police forces, ambulances and other assistance vehicles, and Olympic athletes.

\section{Life inside the Olympic Village}

Inside residential zones in the Olympic Villages (the one in Torino, i.e., the largest, hosted about 2600 persons, mostly athletes and journalists, in more than 100,000 square meters), further controls occurred in the security ring and adjacent streets. Life in the villages was basically separated from the rest of the urban space, with specific events and amenities (like disco parties), which were communicated to the athletes through a newsletter and contributed to creating a sense of community, for example, celebrating birthdays. A shopping centre and a relaxation area were provided inside the village, as were interfaith prayer sessions, Broadway shows, and all sorts of live concerts, special parties, and videogames for the duration of the Games. This kind of internal organization of the life inside the village makes the metaphor of the "bubble" used by Torino Organizing Committee even more pertinent. Its environmental manager puts it this way: "there was everything inside the village, the barbers, the flower shop, the mini-market... it was a sort of Love Boat".$^{34} \mathrm{He}$ was referring to the famous television series from the $1980 \mathrm{~s}$, where all the stories and relationships took place on a cruise ship. This analogy fully grasps the idea of an ideal small world, where everything is provided in order to avert the need to interact with the outside world.

As a form of surveillance over athletes, attention must be paid to drug tests as well. According to the guidelines of the World Anti-Doping Agency and the IOC, controls aim at detecting the use, or potential use, of illicit substances, so as the refusal or faking of biological inspections. Anti-doping analyses have been considered part of the medical services. Every competitive venue and every Olympic village included a 
doping control station, where biological samples were collected every day from a random sample of athletes. After the daily casual choice of the names of the athletes to be checked, volunteers of the Olympic team called "escorts" had to quickly reach the athletes and alert them to go to the doping control station within an hour. Escorts were supposed to follow the athletes during the following hour, in order to avoid actions potentially falsifying the anti-doping analysis. Once at the doping control station, biological samples from the athletes were collected and stored in specific bags. Then, the responsible for the doping control station carried the samples to the central anti-doping lab, where doctors qualified by the Italian Federation for Medical Sport performed the analysis. In case of the detection of drugs, the President of the medical commission informed the IOC executive committee.

\section{How participants evaluated surveillance}

As mentioned above, the head of security of Torino Organizing Committee considers the Torino experience as a successful best practice, and many local politicians celebrated the good performance of the Games. For example, the Minister of the Interior, who was responsible for security stated, in a public conference immediately after the Games: "The wide and sophisticated security system for the Olympic Games has worked perfectly". ${ }^{35}$ As he proudly reported on the Ministery of Interior website website, it even impressed the former mayor of New York, Rudolph Giuliani, who saw the Torino performance as "A perfect example of what to do in presence of terrorist menaces." ${ }^{\prime 36}$

When it comes to measures taken to ensure security, it is difficult to evaluate the perception of the public. A relevant survey was carried on during the events by Lisa Delphi Neirotti: ${ }^{37}$ it refers to questionnaires submitted to three samples of spectators, in the pre-games period, with questions referring to expectations, motivations and services, during the games, referring to issues on the nature of services received, and after the games in relation to impact/overall satisfaction. The questionnaire also asked the spectators to express how they felt about security and the surveillance system to which they were exposed during the Games. The results show that a large majority of the people, $62.7 \%$ described the measures as appropriate. The word evokes ideas of meaningful, reasonable and effective surveillance. A comparison with the Athens Olympics is interesting. As Tsukala analyzes in the previous chapter, two years earlier, the Athens Games were conspicuously saturated with surveillance technologies and procedures and yet, over $73 \%$ of the respondents agreed that these measures were appropriate. The remaining $37.3 \%$ of the respondents in the Torino case were divided between those who perceived the surveillance system as too lenient and others who perceived it as too intrusive.

This general survey confirms the interviews I conducted for the purposes of this chapter. Of the 20 people interviewed, most described the surveillance practices without any particular emphasis. That is, during our conversations, these respondents had no particular memories and no vivid emotions about surveillance practices and technologies used during the Games. I asked the respondents "Do you think it was appropriate, lenient or intrusive?". Of the 20 interviewees 17 reported surveillance as "useful", "appropriate" and "not particularly invasive". Only 3 people found it excessive. These three people were relatively young spectators, one female and two males, between 25 and 35 years of age. All three felt that surveillance was "annoying" and "too rigid" because it prevented them from moving around inside the venues. A young female spectator related the following:

"I was going to see half pipe: I had a place in full tribune, but I wanted to move to the pipe border in order to see the evolution more closely, but there was no way to convince the loyal and dreadfully elderly volunteers." ${ }^{38}$

"Half pipe" is a snowboard competition, and by "full tribune" she meant that she had bought a quite expensive ticket in a privileged part of the spectator area. Her reference to the too-rigid elderly volunteers refers to the fact that, not infrequently, Torino Organizing Committee volunteers in mountain areas were elderly, retired persons who were well trained to perform this task. Here we see that practices of control over space hampered the spectators from moving outside the sector assigned with their ticket. My respondents noticed that these spaces were vacant in that nobody was sitting on those chairs so in their 
mind, these seats were "free", "available" and actually "more enjoyable" because they provided an even better visual angle to the competition. At the same time, in their perception, moving to those chairs would in no way compromise security or the general management of the event. A male spectator related that "It was excessive to block the access to Bardonecchia to every non-resident: in order to get to the venue I had to make an impressively long walk." ${ }^{39}$ Put it differently, he considered the practice of limiting cars circulation annoying and excessive, probably because no particular perils or threats to security were perceived by him. The evaluation of the effectiveness of security is more complicated in the case of working staff, due to the lack of data sources. According to a Torino Organizing Committee manager: "It always seemed to me an accurate service; I don't know if it was excessive, but I think it was inspired by a prevention approach." ${ }^{\prime 0}$

Journalists and sponsors had something different to say. In a file from the Vancouver debriefing after Torino 2006, for example, it is reported that in the main press centre it was "relaxed", with "effective security; enough mag/bag machines to avoid delays." ${ }^{41}$ Another file describes media security as "redundant", affirming that "the venue became a police station rather than a media centre: the constant issue was too many police officers in the venue without proper roles and often without accreditation." 42 Most criticisms come from the sponsors, such as Omega, Samsung, Atos Origin, and Visa: they saw surveillance as something "to be improved", due to difficulties of access to the venues, inconsistent behavior of security representatives, and according to Atos Origin, not enough secure access to the Torino Organizing Committee headquarters..$^{43}$

A different and interesting technical debate following the Games took place during the Vancouver debriefing of 2006, when Cesare Vaciago, the Chief Executive Officer of the Torino Games, affirmed that the use of the mag and bag system was "a waste of money", basically because it required too much personnel, and it could not stop non-metallic weapons. ${ }^{44}$ This position has been strongly criticized by many experts, while others sympathized, affirming that such technologies just gave a "security feeling", and not real control over risks, and that the Olympic committees are lobbied by the producers of such technologies (ibid).

\section{Concluding remarks}

The case of Torino confirms that the management of security involves highly spatialized practices: as described in the chapter, the organization of surveillance involved massive classifications of spaces and flows. Security rings, fences, and rules for the movement of spectators, athletes, workers, cars, goods are all examples of dispositives for controlling the space and the movement of people within the space of the Games. Because of the relatively small dimension of Torino and its neighboring territories, the Games had a massive impact over space in both physical and discursive ways, being intended as an opportunity for the promotion of alternative development paths, and for showing to the world a renewed image of culture and hospitality. The public enthusiasm concerning the Games, with an impressive participation of volunteers (about 18,000) has to be framed in this general imaginary, and confirms the nature of the event as a "recruitment agency" providing, for the local society of Torino, a strong communitas experience. ${ }^{45}$ This probably contributed to a relaxed attitude towards surveillance practices: voices opposing the Games had a limited role, and no particular resistance to the Games and to the practices of body and space control spread during the event ${ }^{46}$ This frames the Torino experience in quite a different way with respect to Beijing 2008 , which will be examined in the next chapter. 


\section{Endnotes}

${ }^{1}$ See A. Vanolo (2008), "The image of the creative city: some reflections on urban branding in Turin", Cities, v. 25, n. 6, pp. 370-382; A. Vanolo (2015), "The image of the creative city, eight years later: Turin, urban branding and the economic crisis taboo", Cities, v. 46, pp. 1-7.

2 "L'attenzione del mondo intero sulla città di Torino e sugli altri Comuni interessati ai Giochi, nonché la presenza di movimenti contrari allo svolgimento degli stessi, hanno imposto l'esigenza di predisporre ed attuare, sia all'interno dei siti, sia nei contesti cittadini e provinciali in cui essi insistono, un sistema di sicurezza volto a garantire, oltre che il regolare svolgimento dei Giochi Olimpici, l'incolumità di quanti, in maniera diretta o indiretta, sono chiamati a parteciparvi. La rilevanza dei XX Giochi Olimpici Invernali e dei IX Giochi Paralimpici Invernali impone che gli stessi si svolgano in una cornice di massima sicurezza, anche per tutelare l'immagine internazionale dell'Italia"; interview with an official of Questura di Torino.

${ }^{3}$ TOROC, Security preliminary strategic plan, Doc. PSP/1- 31/01/2002. Natural risks are not considered in this paper but see Giordano (2005).

${ }^{4}$ http://www.interno.it/olimpiadi/pages/sicurezza_giochi_olimpici/ruolo_mi/ruolo_mi.html (consulted September 2009), my translation.

5 "Il rispetto delle libertà costituzionali di coloro che intendono manifestare ed esprimere le proprie idee in maniera pacifica deve essere garantito"; interview with Functionary of Questura di Torino.

6 "Torinistan e la tregua olimpica", II Foglio, 14 February 2006, p. 3; "Rischio attentati per olimpiadi ed elezioni”, II Giornale, 18 February 2006, p. 11. The sentence quoted in text is extracted from the latter; the full original Italian sentence is "Fra ricorrenti minacce d'ispirazione islamica, tentative di rielavorazioni di un nuovo partito armato, preoccupanti pruriti no global e sbandate politicizzate negli stadi, non c'è da stare poi così allegri”.

7 In December 2005; quoted in M.V. Rizzo (2006), "Il sistema di sicurezza delle Olimpiadi di Torino 2006", Obiettivo sicurezza, n. 1, p. 22-24; p. 22; see also S. Ghieth (2005), "Italy May Suffer Attack Before Olympics, Elections, Pisanu Says", Bloomberg News, http://www.bloomberg.com

${ }^{8}$ See, for example, "La fiaccola si arrende ai No Tav", La Stampa, 6 February 2006, pp. 1, 6-7.

9 "La situazione politica internazionale, lo scenario internazionale, la situazione venutasi a creare in Valle di Susa a causa dei lavori per la realizzazione della TAV richiedono, in occasione dei Giochi Olimpici e Paralimpici, la predisposizione di un dispositivo a tutela dell'ordine e della sicurezza pubblica che prevede anche un complesso sistema di vigilanze agli obiettivi sensibili presenti in Torino e Provincia"; interview with an official of Questura di Torino, my translation.

${ }^{10}$ Information from independent media: http://www.glomeda.org/documenti.php?id=428; http://www.informaazione.info/chiamparino_impera_sullo_sgombero_del_nuovo_fenix (accessed July 2009).

${ }^{11}$ www.nolimpiadi.8m.com (accessed July 2009).

12 www.nolimpiadi.8m.com/militarizzati.html (accessed July 2009).

${ }^{13}$ Personal conversation with TOROC Safety Manager, 20 July 2009. For a (basically) positive account, see also "Tutta colpa del software Tetra. Ha reso inutili i vecchi scanner", La Repubblica, 27 August 2009; see also http://www.protezionecivilecomuneroma.it/sito/upload/documents/torino.pdf.

${ }^{14}$ As denounced on the website http://nolimpiadi.8m.com/sponsor.html (consulted September 2009).

15 "Torino 2006, sventato un attacco informatico", Il Messaggero, 14 February 2006, p. 9; "Olimpiadi, scacco alla sicurezza", http://www.01net.it/01NET/HP/0,1254,0_ART_67692,00.html (accessed July 2009).

16 "Sotto controllo degli investigatori c'è anche l'area antagonista, non solo per possibili gesti clamorosi ma anche per attacchi di pirateria informatica. Proprio venerdì scorso, infatti, era previsto il cosiddetto "netstrike" contro il sito ufficiale dei giochi e quello della Coca Cola (...)", in "Hacker sui cinque cerchi", Il Sole 24 ore, 14 February 2006, p. 11 ${ }^{17}$ Host City Contract, 1999, comma 20.

18 TOROC, Security preliminary strategic plan, Doc. PSP/1- 31/01/2002.

${ }^{19}$ Direttiva per l'organizzazione dei servizi d'ordine e sicurezza pubblica.

${ }^{20}$ Tavolo tecnico and centrale operativa, in Italian.

${ }^{21}$ Centro di coordinamento della sicurezza e di gestione delle emergenze olimpiche; the units in the Olympic venues were called Sale Comando di Sito Olimpico.

22 Interview, TOROC manager, Torino, 20 July 2009, my translation.

${ }^{23}$ Francesco Norante (2006), "Il ruolo della security nelle manifestazioni sportive a carattere mondiale", Essecome, n. 4, pp. 30-38, http://www.securindex.com/articoli/essecome/e4_06Norante_p30-38.pdf (consulted September 2009). ${ }^{24}$ Interview with TOROC environmental manager, Torino, 25 September 2009.

25 "Torino 2006, sventato un attacco informatico", II Messaggero, 14/2/2006, p. 9; "Hacker sui cinque cerchi", II Sole 24 ore, 14/2/2006, p. 11; "Olimpiadi, scacco alla sicurezza", http://www.01net.it/01NET/HP/0,1254,0_ART_67692,00.html (accessed July 2009). 
26 “E' stata pertanto resa attiva un'organizzazione dei dispositivi di sicurezza adeguati con le possibili minacce. Su tutto è prevalso 'lo spirito olimpico', ed è stato perciò limitato al massimo l'impiego visibile delle Forze di Polizia pur mantenendo sempre alto e vigile il livello di sicurezza";

http://www.interno.it/olimpiadi/pages/sicurezza_giochi_olimpici/ruolo_mi/ruolo_mi.html (consulted September 2009), my translation.

${ }^{27}$ Available, in both Italian and English, on

http://www.torino2006.it/ENG/OlympicGames/vieni_a_torino2006/guide.html (consulted September 2009).

${ }^{28}$ Interview with spectator, Torino, 12 July 2009; interview with TOROC environmental manager, Torino, 25

September 2009, my translations.

29 "Excuse me, but your label is showing"; www.msnbc.msn.com/id/11414718 (access July 2009).

${ }^{30}$ European Union Regulation n. 2046/205.

${ }^{31}$ Torino 2006, Final Report (official concluding report developed for IOC).

32 "Ogni mattina ero sottoposto al mag and bag, a prescindere dal fatto che, dopo mesi di lavoro, il poliziotto e io ci conoscevamo benissimo, e dal mio badge di accredito. Era un controllo simili a quelli degli aeroporti"; interview with TOROC environmental manager, Torino, 25 September 2009, my translation.

${ }^{33}$ For a full description, see G. Pisapia (2006), "Security and logistics in a major sport event: the vendor certification program (VCP) of the XX Winter Olympic Games"; and G. Pisapia (2006), "The security system of the XX Winter Olympic Games", both available at www.itsitme.it (consulted October 2009).

34 "C'era tutto nel villaggio: il barbiere, il negozio di fiori, il mini-market... era una specie di Love Boat"; interview with TOROC environmental manager, Torino, 25 September 2009, my translation.

35 “'L'ampio e sofisticato sistema della sicurezza messo in campo per le olimpiadi di Torino ha funzionato alla perfezione"; Viminale, 27 February 2006; http://www.interno.it/olimpiadi/pages/news/Conf_stampa_viminale.html (Consulted September 2009), my translation.

36 "Esempio perfetto di quello che bisogna fare in presenza di minacce terroristiche"; http://www.interno.it/olimpiadi/pages/news/giuliani.html (consulted September 2009), my translation.

${ }^{37}$ A short presentation of the results is available as: File \#72, "Spectator and General Public Experience", in The Torino 2006 Olympic Experience. The Official Debriefing \& Final Analysis of the XX Olympic Winter Games, Torino 2006 dvd. A deeper survey on the data and analysis has been kindly furnished by the author. However, no specific data concerning the statistical size of the sample were presented.

38 "Ero andata a vedere l'half pipe: sebbene avessi il posto in piena tribuna, volevo spostarmi a bordo del pipe per vedere più da vicino le evoluzioni ma non c'è stato verso di convincere i ligi e temibili anziani volontari"; interview with spectator, 14 July 2009, my translation.

39 "Era assurdo bloccare l'accesso a Bardonecchia ai soli residenti; per accedere alla struttura della gara c'era da fare un giro impressionante"; interview with spectator, 14 July 2009, my translation.

40 "Mi è sempre sembrato un servizio accurato; non so dire se fosse eccessivo, ma immagino fosse ispirato a un principio di prevenzione"; interview with TOROC environmental manager, Torino, 25 September 2009, my translation

${ }^{41}$ File \#42, "Torino 2006 Olympic Experience. Part 3, Olympic Stakeholder Experience”, in The Torino 2006 Olympic Experience. The Official Debriefing \& Final Analysis of the XX Olympic Winter Games, Torino $2006 \mathrm{dvd}$.

42 File \#79; see also, "A Few Words about Security at the Olympics", http://olympics.about.com/b/a/000024.htm.

${ }^{43}$ Respectively Files \# 62, 64, 68, 69, in The Torino 2006 Olympic Experience. The Official Debriefing \& Final Analysis of the XX Olympic Winter Games, Torino $2006 \mathrm{dvd}$.

${ }^{44}$ A full description of the debate is available on The Torino 2006 Olympic Experience. The Official Debriefing \& Final Analysis of the XX Olympic Winter Games, Torino 2006 dvd; see also "Just how much security do those X-ray machines provide? Not much"; http://communities.canada.com (access July 2009).

${ }^{45}$ MacAloon J. (1984), Olympic Games and the theory of spectacle in modern societies, in J. MacAloon (ed.), Rite, Drama, Festival, Spectacle: Rehearsals Toward a Theory of Cultural Performance, Institute for the Study of Human Issues, Philadelphia, pp. 241-280. See also, for the specific case of Turin, A. Vanolo (2015), "The image of the creative city, eight years later: Turin, urban branding and the economic crisis taboo", Cities, v. 46, pp. 1-7.

${ }^{46}$ See E. Dansero, B. Del Corpo, A. Mela and I. Ropolo (2012), Olympic Games, Conflicts and Social Movements: The Case of Torino 2006, in G. Hayes and J. Karamichas (eds.), Olympic Games, Mega-Events and Civil Societies, Palgrave Macmillan, New York, pp. 195-281. 